UDC 159.922.6:376-056.26

DOI https://doi.org/10.30970/PS.2021.9.19

\title{
THE FACTORS OF ONTOGENESIS AND DYSONTOGENESIS OF ADOLESCENTS' PERSONAL FORMATION
}

\author{
Olena Lytvynenko \\ Borys Grinchenko Kyiv University, \\ 18/2, I. Shamo boulevard, Kyiv, Ukraine, 02154 \\ e-mail: o.lytvynenko@kubg.edu.ua
}

Adolescence is a period of numerous crises and transformations, changes in behavioural patterns, emotional and cognitive spheres. The course of adolescence largely determines the overall quality of subsequent human life. Therefore, a fundamental study of the psychological characteristics of this age period is unquestionably important. The article presents the results of a study of adolescents' personal sphere. The aim of the study was to identify and analyse specific factors of ontogenesis and dysontogenesis of personal formation. The methods of empirical research were Individual typology questionnaire, Dusseldorf Illustrated Schema Questionnaire for Children and the content analysis of personal narratives. Statistical processing of the obtained data was carried out using factor analysis. The results of the study indicate the presence of three groups of factors: general (common to all adolescents), factors of ontogenesis (typical for adolescents, whose development is conditionally normative), factors of dysontogenesis (typical for adolescents who have hearing and vision impairments). Presented factors describe the core cognitive beliefs of adolescents about the world around them and their place in this world, their leading emotional states, as well as the most typical behavioural patterns. Thereby it was proved that functional dysontogenesis not only determines cognitive development of adolescents, but also influences their personal features and behavioural characteristics. Understanding the psychological content of identified factors allows to explain the structure of the personal sphere of adolescents and to formulate the principles of training work with them, aimed at harmonizing their personal development. The prospects of further researches in this area are connected with identifying whether the proposed factors are typical for the representatives of other age categories: adults and children.

Key words: adolescence, ontogenesis, dysontogenesis, personal factors, maladaptive schemas, core beliefs, content analysis.

Introduction. Adolescence is a period of intensive personal development. At this time there are formed numerous personal characteristics, features, traits, behavioural patterns and core beliefs. Obviously, the peculiarities of adolescence depend on a number of factors. Such factors include social situation of development, the availability of external and internal resources, general personal resilience etc. In addition, the genetic aspect of development (ontogenesis or dysontogenesis of personal formation) is important and should be taken into account. The dysontogenesis is understanded as a development in the context of physiological disorders that do not have a direct impact on the human psyche, but determine its general psychological orientation. In this case, such disorders included hearing and visual impairments.

Thereby the aim of this study was to identify and analyse specific factors of ontogenesis and dysontogenesis of personal formation. Achieving the aim became possible by performing the following tasks: 1) to investigate the manifestations of cognitive, affective and behavioural spheres of adolescents' personality; 2) to define factors of personal formation of adolescents on the basis of the received data; 3 ) compare the factors of ontogenesis and dysontogenesis and identify general trends and specific manifestations.

(C) Lytvynenko Olena, 2021 
Literature review. The results of the studies of personal formation indicate that the development of adolescents with hearing impairments occurs at the same stages as their healthy peers, but the transition from one stage to another may be delayed [1]. Similar data were also obtained regarding the personal development of children and adolescents with visual impairments [2]. On the other hand, Bilyk and Vasylenko note that the personality structure of adolescents with visual impairments includes some specific features and characteristics. These features make a destructive effect on the interpersonal interaction, which hinders social development and slows down general personal formation [3]. However, in the case of favourable conditions and the inclusion in the context of social interaction, personal formation meets the requirements of the age norm [4].

Analysing the personality of adolescents with hearing and visual impairments, as well as their peers who do not have such impairments, we studied the peculiarities of three personal spheres: cognitive, affective and behavioural.

The cognitive sphere was represented by maladaptive cognitive schemas, which are formed in childhood. Depending on the life situation, experience of relationship, individual coping mechanisms they can change throughout life. If the existing schema is activated, strong negative emotions such as anxiety, sadness or feelings of loneliness appear [5]. Any person can have one schema or a combination of several schemas. As a rule, people have more or less stable schemas [6]. The schema is considered to be maladaptive only when it is associated with pathological emotional experiences and symptoms or disorders of social functioning. Young identified 18 schemas, which are grouped into five clusters [7]. Individuals with severe personality disorders typically score high on many of the Young's questionnaire schemas. These 18 schemes formed the basis of personal factors we have identified.

Emotional traits that determine the nature of person's affective response to events and phenomena of the world are emotionality, aggression, sensitivity and anxiety. Their analysis allows deepening the understanding of the affective sphere of personality [8].

Among the typical behavioural reactions of individual, there can be distinguished five leading strategies: 1) active, aggressive actions; 2) intellectualization; 3) seeking the alternatives; 4) seeking social support and 5) avoidance. The choice of behavioural strategy on the one hand is determined by the personal characteristics of the subject, and on the other hand forms the structure and specificity of his personality [9]. Thus, the definition of these strategies leads to understanding of the behavioural sphere of the personality.

Presented results of separate scientific researches have put the question about the general personal features of adolescents who have impairments in work of analysers and their peers who do not have such impairments. It became possible to answer this question by studying the structure and manifestations of their personal sphere and identifying the factors of ontogenesis and dysontogenesis of adolescents' personal formation.

Methodology. The empirical research lasted during 2015-2020 years. Total number of respondents was 535 but the sample was divided into three groups: 1) group A - respondents with hearing impairments (180 people); 2) group B - respondents with visual impairments (110 people); 3) group C (conditionally normative group) - respondents without any impairments in the work of analysers (245 people). All the respondents were 12-17 years old and studied at secondary schools and special educational institutions in different cities of Ukraine.

The analysis of dynamic features of ontogenesis and dysontogenesis of adolescents' personal formation allowed to make assumptions which formed the basis of two statistical hypotheses: 1) about the availability of specific adolescents' personal factors; and 2) about the differences between personal factors of ontogenesis and dysontogenesis. These hypotheses were tested with the help of factor analysis in the form of principal components method with oblimin 
rotation. Important that we did not have a hypothesis about the independence of potential factors, so we chose this type of rotation, which can detect both dependent and independent factors.

In order to identify universal and generalized characteristics of the respondents' personalities there were combined the manifestations of three personality spheres (cognitive, affective and behavioural). Among the characteristics of cognitive sphere there were taken the maladaptive cognitive schemas. The affective sphere was characterised by emotional personality features and the behavioural sphere - by the typical strategies of behaviour. The methods of empirical research were Dusseldorf Illustrated Schema Questionnaire for Children [10], Individual typology questionnaire [11] and the content analysis of personal narratives.

To test the hypothesis of differences between the personality factors of adolescents, whose formation occurs in the context of ontogenesis and dysontogenesis, data factorization was performed separately for each group of respondents. The method of parallel factor analysis was used to determine the number of principal components.

Research results. The analysis of the group $\mathrm{C}$ graph of the factors eigenvalues decrease allowed to identify 10 factors that reveal $70 \%$ of the combined variation of indicators, which is a fairly high result. During the interpretation of the results we took into account only the factor loads that are higher than 0,1 and may be important for the analysis of the obtained factors. Note that these factors are not typological but individual characteristics. So in some form they can be inherent to all subjects.

The first factor ( $11 \%$ of variance) can be called the avoidance factor, because the largest factor loading of it is on cognitive schemas of disconnection and rejection (defectiveness $-0,86$; mistrust - 0,73; emotional deprivation - 0,70; alienation - 0,54). Respectively, this factor determines the feeling loneliness and disability to set warm and trustful relationship.

The second factor ( $9 \%$ of variance) is a coping factor, which does not include statistically significant loads on the factors of maladaptive schemas but offers the implementation of behavioural strategies that help to overcome life difficulties (active, aggressive actions - 0,99; intellectualization - 0,55).

The third factor ( $8 \%$ of variance) can be called affective, due to the manifestations of emotional personality traits (sensitivity $-0,81$; emotionality $-0,60$ ), as well as the activation of the enmeshment cognitive schema $(0,66)$, which is connected with the believes that support a tendency to unconditional focus on thoughts and emotions of others.

The fourth factor ( $7 \%$ of variance) is a factor of generalized anxiety, as the greatest factorial loading within it is on personal anxiety $(0,57)$ and cognitive schema of vulnerability $(0,72)$, which can be a background for the formation of generalized anxiety disorder.

In the structure of the fifth factor ( $7 \%$ of variance) there is a dominance of cognitive schemas of other-directedness (approval-seeking - 0,80) and impaired limits (grandiosity - 0,61; Insufficient self-control - 0,59), as well as a fairly pronounced expression of emotional personality traits (emotionality $-0,50$ ). Therefore, this factor can be called a factor of demonstrativeness.

A characteristic feature of the sixth and the seventh factors (total $12 \%$ of variance) is a significant number of cognitive schemas. These factors are responsible for the formation and actualization of adolescents' dysfunctional beliefs about themselves and the world around them. The main characteristic of the sixth factor is focus on schemas of over-vigilance and inhibition (over-control - 0,81; punitiveness - 0,79), which allows calling it a factor of mistrust of the world. The main factorial loads of the seventh factor 7 are on the schemas of impaired autonomy and performance (dependence - 0,73; enmeshment - 0,65; failure - 0,51). That is why it can be called a factor of self-doubt.

The eighth factor ( $6 \%$ of variance) is also characterized by wide manifestations of maladaptive schemas. However, its defined characteristic is the significant factorial load of the per- 
sonal aggressiveness $(0,81)$ and the complete absence of coping behaviour. Thus, this factor can be conditionally called the surrender factor.

The ninth factor ( $5 \%$ of variance) can be called a conformist factor, because it contains schemas that determine the individual's interaction with others, as well as the behavioural strategy of seeking social support $(0,87)$.

Finally, the tenth factor ( $5 \%$ of variance) is characterized by an insignificant, and sometimes negative load on the cognitive schemas combined with the obvious manifestation of the behavioural strategy of seeking the alternatives $(0,88)$. It allows to call the last ontogenetic factor of adolescents' personal formation a factor of dimensional activity.

The next step in testing the hypothesis was the factorization of the characteristics of respondents who have hearing and vision impairment. It was decided to conduct separate procedures of factor analysis for each of these groups of subjects. The analysis of group A results confirmed the 10-factor structure, which was also typical for group C. At the time, factor analysis revealed $68 \%$ of the compatible indicators variation, which was also sufficient for further generalizations. Systematization of the results of factor analysis allows us to talk about the general patterns as well as about principle differences, typical for group A. Particularly, we can note the coincidence of the first two factors, except for some minor differences. Thus, the avoidance factor $(12 \%$ of variance) is characterized by a slightly lower load of the variables, which correspond to maladaptive cognitive schemas (defectiveness - 0,77 ; mistrust - 0,76 ; emotional deprivation 0,75 ; alienation - 0,57). That means, that the avoidance factor of adolescents with hearing impairments differs in the strength of the manifestation.

At the same time, the coping factor ( $9 \%$ of variance) is characterized not only by a significant manifestation of individual behavioural strategies (active, aggressive actions $-0,98$; intellectualization - 0,54), but also by the presence of some maladaptive schemas. Note that for the normative sample, the coping factor was "pure" (characterized by the complete absence of maladaptive schemas). However, the isolated differences do not fundamentally affect the internal content of factors and, accordingly, allow to correlate them with similar factors of ontogenesis.

The third and fourth factors for group A are characterized by the complete absence of both coping strategies and emotional manifestations. The third factor ( $8 \%$ of variance) includes the schemas of social isolation $(0,70)$ and negativism $(0,79)$, which allows to call it a factor of mistrust of people. Instead, the main emphasis in the fourth factor ( $7 \%$ of variance) is shifted towards schemas of insufficient self-control $(0,80)$ and unrelenting standards $(0,64)$. Respectively, we can call it a factor of egocentrism.

The fifth factor ( $6 \%$ variance), in addition to a fairly wide representation of maladaptive schemas and the absence of coping behaviour, similar to the previous two factors, is also characterized by a negligible negative load of emotional personality traits (emotionality - $-0,70$; aggressiveness - $-0,64$; sensitivity - - 0,53 ). In that way it determines the manifestation of unconstructive core beliefs, combined with the suppression of emotions. That is why we can call it a factor of emotional inhibition. In this context, it can be contrasted to the group $\mathrm{C}$ affective factor.

The sixth factor $(6 \%$ of variance) of this sample can be correlated with the generalized anxiety factor identified in the previous stage of statistic analysis. It also includes the manifestations of personal anxiety $(0,68)$ and a schema of vulnerability $(0,51)$. However, in this case, the factor loads are less pronounced than those found in the sample of respondents whose personal formation occurs in the context of ontogenesis. However, the presented differences are not fundamental, which allows us to attribute this factor to generalized anxiety.

The seventh factor ( $6 \%$ of variance) is in some way similar to the previously detected affective factor. But, as in previous cases, here we can observe a lower intensity of the qualities that form the basis of its content. However, this time the intensity of differences is such that does not 
allow to combine this factor with the affective one. That is why according to the general logics of the factor's content, we can call it a factor of restrained affectivity.

The core characteristic of the eighth factor ( $5 \%$ variance) is the focus on the behavioural strategy of seeking social support $(0,54)$ and the actualization of cognitive schemas of enmeshment $(0,79)$ and dependence $(0,76)$. Taking into account peculiarities of the manifestation of these schemas, e.g. disbelief in personal value, orientation to the others' opinion, inability to make independent decisions etc., this factor can be called a factor of dependency.

The ninth factor ( $5 \%$ variance) is characterized by a manifestation of intellectualization behavioural strategy $(0,85)$ and negative factor loads on most schemas. Thus, this factor is responsible for the ability to overcome difficulties through analytical data processing and informed decision-making. According to its leading strategy this factor can be called factor of intellectualization.

The tenth factor found in this sample (5\% variance) is quite authentic and different from the others. Its principal features are a high propensity of self-sacrifice $(0,83)$, a manifestation of personal sensitivity $(0,54)$, as well as a negative factor load on the scale of aggressiveness $(-0,53)$. This factor is connected with the individual's tendency to empathize others and the willingness to provide help and support to those who need it. That is why it can be called a factor of empathy.

Thus, the results of factor analysis for adolescents with hearing impairments allowed us to talk about 10 factors. It corresponds to the number of factors obtained in the normative sample. In this case, 3 out of 10 factors are common for the two samples, taking into consideration the sufficient number of identical features in their content. The other 7 factors differ depending on the presence of hearing impairments and the impact of auditory deprivation on the process of personal development.

The third stage of data factorization was a factor analysis for indicators obtained from a study of group B. As a result the 10-factor structure of the personal sphere of adolescents was confirmed for the third time. The overall rate of variation was $70 \%$, which, as in the previous two cases, is sufficient for further generalizations.

The first personal factor was once again an avoidance factor (12\% variance), which indicates its universality for the adolescents, regardless of the genetic aspect of their personal development. The corresponding result is also observed with the second factor - coping $(9 \%$ variance). The other 8 factors are more specific and should be considered separately.

The third factor ( $8 \%$ variance) is characterized by a manifestation of self-sacrifice cognitive schema $(0,79)$, the tendency to choose a behavioural strategy of seeking social support $(0,52)$ and a high level of personal sensitivity $(0,50)$. It allows to identify this factor with the empathy factor, which is also typical for adolescents from the group B.

The structure and content of the fourth factor ( $7 \%$ variance) are almost identical to the factor of emotional inhibition found in a sample of adolescents with hearing impairments. This factor is also characterized by a fairly wide representation of maladaptive schemas and the absence of patterns of coping behaviour. The other characteristic of this factor is a significant negative load on the emotional individual features. Thus, it can also be called a factor of emotional inhibition.

The fifth factor ( $7 \%$ variance) is characterized by a significant manifestation of the cognitive schemas of emotional inhibition $(0,75)$, as well as abandonment $(0,78)$ and other schemas from the group of disconnection and rejection. Thus, this factor is responsible for the desire of adolescents to hide their own emotions and feelings because of the fear that they will lead to conflicts with significant others. Thereafter, we can call it a factor of impaired affiliation.

The sixth factor ( $6 \%$ variance) includes maladaptive cognitive schemas of subjugation $(0,63)$ and punitiveness $(0,53)$, as well as a significant negative load on the individual feature of 
aggressiveness (-0,71). Accordingly, the manifestation of this factor is associated with the refusal to defend personal boundaries and with the avoidance of confrontation with others, which allows to call it a factor of violated boundaries.

The seventh factor ( $6 \%$ variance) is characterized by the complete absence of emotional personality traits and insignificant manifestation of coping strategies in combination with a pronounced cognitive schema of entitlement $(0,71)$. Thus, it can be conditionally called a factor of its self-exclusivity.

The next, eighth factor ( $5 \%$ variance) can be correlated with the affective factor identified during the analysis of group $\mathrm{C}$ results, due to their completely similar content. The ninth factor ( $5 \%$ variance), can also be correlated with the previously identified for group A factor of mistrust of people. In turn, the tenth factor (5\% variance) differs from the previous ones and is characterized by a manifestation of a maladaptive schemas of recognition-seeking $(0,59)$, as well as negative loads on variables that correspond to the behavioural strategy of searching the alternatives $(-0,74)$ and personal sensitivity $(-0,56)$. In view of this, we can call it a factor of self-affirmation.

Conclusions. The obtained results allow to analyse the general structure of adolescents' personal manifestations that depend on the ontogenetic or dysontogenetic context of their formation. The system of adolescents' personality peculiarities proves the existence of factors that can be conditionally attributed to the category of the general (those that are common to all adolescents outside the genetic context of their personal formation). This category includes avoidance and coping factors. The avoidance factor is connected with the subject's fear of being excluded from the community; anxiety related to the opinion of others about him; self-doubt and low self-esteem. These traits are quite typical for adolescence, when belonging to a group of significant others becomes a basic need and at the same time the leading activity of the person. So the self-esteem fluctuations and its dependence on external assessments are relatively normative. Thus, the avoidance factor can be considered a centre of typical for adolescents dysfunctional affective, cognitive and behavioural manifestations.

On the other hand, the coping factor is characterized by the absence of maladaptive cognitive schemas in combination with pronounced patterns of coping behaviour in difficult life situations. That is why this factor is responsible for a healthy and harmonious perception of one self and others, as well as for the overall resilience of adolescents and their ability to overcome difficulties and to maintain their own psycho-emotional well-being. Accordingly, we can conclude that, regardless of the context of personal formation, there are two personality factors that form a certain continuum of manifestations from dysfunction to harmony. The strength of the manifestation of each of these factors determines the systematic organization and representation of personal qualities.

Other excreted factors turned out to be more specific and limited in their manifestation. Thus, two factors inherent to adolescents from the normative sample and their peers with hearing and visual impairments were identified. These were the generalized anxiety factor (for groups A and $\mathrm{C}$ ) and the affective factor (for groups B and C). However, the most common factors were found between groups A and B. In particular, adolescents with hearing and visual impairments tend to have the factors of empathy, emotional inhibition and mistrust of people. It means that such adolescents, to a greater extent than their peers from the normative group, tend to refrain from expressing their own feelings and experiences, as well as to show suspicion towards others and need more time to get used to new people in their own environment. At the same time, after passing the stage of adaptation, they usually are more sympathetic, open to compassion and empathy.

Thus, taking into account two general factors common to all adolescents and three factors common to representatives of groups $\mathrm{B}$ and $\mathrm{C}$, we can state the coincidence of 5 factors. 
This allows to make a conclusion, that personal structure of adolescents with hearing and visual impairments is $50 \%$ identical. In this way it proves the existence of specific dysontogenesis factors of personal formation. These factors not only incorporate samples of adolescents with visual and hearing impairments, but also distinguish them from their peers who do not have such impairments.

Identified trends confirm statistical hypothesis about the availability of ontogenesis and dysontogenesis factors and determine the further logic of empirical study of the adolescents' personal sphere. Moreover, the perspectives of further work in this area are connected with the implementation of received data into the psychological practice and consideration of described factors in the process of counseling and psychotherapy.

\title{
References
}

1. Vernon M., Andrews J. The psychology of deafness. Longman, 2010. 375 p.

2. Moschos M.M. Physiology and Psychology of Vision and its Disorders. Medical Hypothesis, Discovery \& Innovation. 2014. № 3. P. 83-90.

3. Білик Ю.В., Василенко О.М. Особливості життєдіяльності дітей з вадами зору. Науковий вісник Ужгородського начіонального університету. 2012. № 35. С. 32-34.

4. Коган Б.М., Яковлева А.В. Личностные характеристики слабовидящих подростков. Специальное образование. 2012. № 2. С. 62-67.

5. Арнц А. Схема-терапія: модель роботи з частками. Львів : Галицька видавнича спілка, 2020. $264 \mathrm{c}$.

6. Лозова О.М., Литвиненко О.О. Наративні індикатори дисфункційних когнітивних схем підлітків. Психолінгвістика. 2019. № 26 (1). С. 228-245.

7. Young J., Klosko J., Weishaar M. Schema Therapy. Guilford Press, 2003. 412 p.

8. Telzer E., Goldenberg D., Fuligni A., Galván A., Lieberman M. Adolescents' emotional competence is associated with parents' neural sensitivity to emotions. Frontiers in Human Neuroscience. 2014. № 8. P. 558-568.

9. Silk J., Steinberg L., Morris A. Adolescents' emotion regulation in daily life: links to depressive symptoms and problem behaviour. Child Development. 2003. № 74 (6). P. $1869-1880$.

10. Loose Ch., Meyer F., Pietrowsky R. The Dusseldorf Illustrated Schema Questionnaire for Children (DISC). Reflexão e Crítica, 2018. 18 p.

11. Собчик Л.Н. Теория и практика психологической оценки личности. Московский психологический журнал. 2002. № 3. С. 85-89.

\section{ФАКТОРИ ОНТОГЕНЕЗУ ТА ДИЗОНТОГЕНЕЗУ ОСОБИСТІСНОГО СТАНОВЛЕННЯ ПІДЛІТКІВ}

\author{
Олена Литвиненко \\ Київський університет імені Бориса Грінченка, \\ бульв. І. Шамо, 18/2, Київ, Украӥна, 02154 \\ e-mail: o.lytvynenko@kubg.edu.ua
}

Підлітковий вік - це період численних криз та трансформацій, змін у поведінкових моделях, емоційній та когнітивній сферах. Перебіг підліткового віку багато в чому визначає загальну якість подальшого людського життя. Тому фундаментальне дослідження психологічних особливостей цього вікового періоду є, безперечно, важливим. У статті представлені результати емпіричного дослідження особистісної сфери підлітків, які мають порушення слуху, порушення зору, та їхніх однолітків, котрі не мають таких порушень. Метою наукового пошукування було виявити та проаналізувати специфічні фактори онтогенезу та дизонтогенезу становлення особистості. В якості методів емпі- 
ричного дослідження було застосовано індивідуально-типологічний опитувальник, Дюссельдорфський опитувальник схем для дітей та контент-аналіз персональних наративів. Статистична обробка отриманих даних проводилась із застосуванням факторного аналізу. Результати дослідження вказують на наявність трьох груп факторів: загальних (притаманних усім підліткам), факторів онтогенезу (типових для підлітків, розвиток яких є умовно нормативним), факторів дизонтогенезу (типових для підлітків, які мають порушення слуху та зору). Представлені фактори описують глибинні когнітивні переконання підлітків про навколишній світ та своє місце в ньому, їхні провідні емоційні стани, а також найбільш типові поведінкові моделі. Отже, доведено, що функціональний дизонтогенез не тільки визначає когнітивний розвиток підлітків, але й впливає на їхні особистісні якості та особливості поведінки. Розуміння психологічного змісту виокремлених факторів дозволяє пояснити структуру особистісної сфери підлітків та сформулювати принципи психологічної роботи з ними, спрямованої на гармонізацію їхнього особистісного розвитку. Перспективи подальших досліджень у цій сфері вбачаємо у визначенні того, чи $є$ запропоновані фактори типовими для представників інших вікових категорій: дорослих та дітей.

Ключові слова: підлітковий вік, онтогенез, дизонтогенез, особисті фактори, неадаптивні схеми, основні переконання, аналіз змісту. 